\title{
KURANGI DAMPAK BENCANA MELALUI KEMATANGAN MITIGASI BENCANA BERBASIS MASYARAKAT DI KELURAHAN UTAMA KOTA CIMAHI
}

\author{
Asep Badrujamaludin ${ }^{1}$, Diki Ardiansyah ${ }^{2}$, Dyna Apriany ${ }^{3}$, Dwi Hastuti ${ }^{4}$, Oop \\ Ropei $^{5}$, Tria Firza Kumala ${ }^{6}$ \\ ${ }^{1-5}$ Program Studi Keperawatan D3, STIKES Jenderal A. Yani Cimahi \\ Email: dru.stikesr@gmail.com
}

\begin{abstract}
ABSTRAK
Hasil kajian terbaru tahun 2017 menunjukkan laju pergeseran sesar Lembang sekitar 3,0- 5,5 mm/tahun. Angka ini bertambah dari prediksi tahun 2011 yang menyebut laju pergeserannya sekitar 2,0 - 4,0 mm/tahun. Selain itu, riset terbaru dari Pusat Penelitian Geoteknologi LIPI menemukan bahwa panjang sesar ternyata 29 kilometer, bukan 22 kilometer sebagaimana acuan peneliti sebelumnya. Kekuatan gempa akibat pergeseran sesar lembang melintang sepanjang 29 kilometer dari ujung barat di Kecamatan Ngamprah Kabupaten Bandung Barat sampa sisi tmur di Kecamatan Cilengkrang Kabupaten Bandung yang memungkinkan mengakibakan getaran gempat 6,8 sampai 7 skala richter. Dengan kekutan gempa sebesar itu, wilayah Kota Cimahi termasuk kota yang berpotensi tinggi mendapatkan dampak dari pergerakan sesar lembang tersebut. Hal ini juga disampaikan oleh Badan Penanggulangan Bencana Daerah (BPBD) Kota Cimahi menyatakan Kota Cimahi merupakan wilayah yang berpotensi mendapatkan dampak jika terjadi gempa bumi akibat pergerakan sesar lembang. Melihat tingginya potensi dampak ancaman bencana gempa bumi pada wilayah kerja Puskesmas Cimahi Selatan, perlu adanya upaya persiapan penanggulangan bencana dengan sasaran masyarakat risiko tinggi seperti anak SD dan kelompok warga seperti kader di wilayah tersebut. Kegiatan pengabdian masyarakat ini berupa kegiatan-kegiatan yang bertujuan untuk meningkatkan pengetahuan terkait ancaman bencana serta penanggulangan bencana yang dimulai dari tahap prabencana, intrabencana sampai pasca bencana. Kegiatan ini akan dilaksanakan dengan bentuk kegiatan berupa penyuluhan, demonstrasi dan simulasi. Dengan memasukan kegiatan upaya penanggulangan bencana secara komprehensip dengan bentuk kegiatan simulasi, masyarakat akan lebih mudah dan cepat mengetahui upaya-upaya yang harus dilakukan sebagai upaya penanggulangan bencana. Kegiatan-kegiatan dalam upaya penanggulangan bencana gempa di wilayah ini juga merupakan salah satu langkah solusi dalam meningkatkan persiapan menghadapi bencana serta dapat mengurangi kemungkinan jumlah korban bencana. Kegiatan pengabdian masyarakat ini menggunakan metoda sosialisasi melalui pertemuan/diskusi dengan kelompok mitra berupa seminar/penyuluhan, demonstrasi dan simulasi penanggulangan bencana pada setiap tahap (pra, intra dan paska bencana). Hasil kegiatan pengabdian masyarakat ini menambah pemahaman secara teori dan juga praktik simulasi terkait mitigasi bencana para kader kesehatan di kelurahan utama.
\end{abstract}

Kata Kunci : Penanggulangan Bencana, Kesiapsiagaan Bencana, Sesar Lembang 


\section{ABSTRACT}

The results of the latest study in 2017 show the rate of displacement of the Lembang fault around $3.0-5.5 \mathrm{~mm} /$ year. This figure is increased from the prediction in 2011 which states that the rate of shift is around $2.0-4.0 \mathrm{~mm} /$ year. In addition, the latest research from the LIPI Geotechnology Research Center found that the length of the fault was 29 kilometers, not 22 kilometers as previously referred to by previous researchers. The strength of the earthquake was due to a transverse shift of the Lembang fault along 29 kilometers from the west end in Ngamprah District, West Bandung Regency to the east side in Cilengkrang District, Bandung Regency which made it possible to cause tremors of 6.8 to 7 on the Richter scale. With the magnitude of the earthquake, the Cimahi City area is a city with high potential to be impacted by the movement of the lembang fault. This was also conveyed by the Regional Disaster Management Agency (BPBD) of Cimahi City, stating that Cimahi City is an area that has the potential to be impacted if an earthquake occurs due to the movement of the Lembang fault. Seeing the high potential impact of the threat of an earthquake disaster in the work area of the South Cimahi Puskesmas, it is necessary to prepare for disaster management with the target of high-risk communities such as elementary school children and community groups such as community health providers in the area. This community service activity takes the form of activities aimed at increasing knowledge related to disaster threats and disaster management starting from the pre-disaster, inter-disaster to postdisaster stages. This activity will be carried out in the form of activities including counseling, demonstrations and simulations. By incorporating disaster management efforts comprehensively with the form of simulation activities, the community will find it easier and faster to know the efforts that must be made as disaster management efforts. Activities in earthquake disaster management in this area are also one of the solution steps in increasing the preparation for facing disasters and reducing the possibility of the number of victims of disasters. This community service activity uses the socialization method through meetings / discussions with partner groups in the form of seminars / counseling, demonstrations and simulations of disaster management at every stage (pre, intra and post disaster). The results of this community service activity add to the theoretical understanding and also simulation practice related to disaster mitigation for health cadres in the Kelurahan Utama.

Keyword: Disaster Management, Disaster Preparedness, Sesar Lembang

\section{PENDAHULUAN}

Indonesia merupakan salah satu negara paling rawan bencana di dunia, seringkali dan tidak terduga, yaitu di antaranya gempa bumi, tsunami, tanah longsor, letusan gunung berapi, banjir, dan kekeringan (CFE-DM, 2018 dalam Fernalia et. Al, 2019). Berdasarkan indeks Rawan Bencana Indonesia 2013, Kota Cimahi memiliki tingkat risiko bencana yang cukup tinggi dengan skor 120 atau berada pada skala kerawanan sedang. Bencana alam seperti longsor, banjir dan gempa bumi di Cimahi berisiko lebih tinggi, apabila cuaca ekstrim akan mempengaruhi kondisi klimatologi, topologi dan geohidrologi. Di wilayah Cimahi Selatan menurut Badan Penanggulangan Bencana Daerah (BPBD) Kota 
Cimahi, wilayah cimahi selatan merupakan wilayah cekungan yang memungkinkan terjadinya banjir. Selain itu, adanya sesar lembang menjadikan cimahi selatan menjadi salah satu wilayah yang memiliki risiko dampak yang cukup tinggi. Sedangkan analisis situasi dari luas wilayah Cimahi Selatan 16,94 km² dengan kepadatan penduduk pada tahun 2017 sebanyak 16.210 perKm $^{2}$ (Profil Kesehatan Cimahi 2017). Hal tersbut menunjukkan bahwa dari tingkat kepadatan penduduk yang cukup padat, wilayah Cimahi Selatan memungkinkan akan terjadinya dampak korban bencana gempa bumi dengan jumlah korban yang cukup banyak apabila dilihat dari tingkat kepadatan penduduk.

Hasil Analisis situasi dari jumlah pendudukan menurut tingkat pendidikan di Kecamatan Cimahi Selatan menunjukkan sebanyak 80.145 jiwa dengan tingkat pendidikan SLTA dan ini menjadi jumlah paling tinggi di wilayah Cimahi Selatan. Selain itu, urutan kedua tingkat pendidikan masyarakat di wilayah ini adalah sekolah dasar (SD). Hal ini menunjukkan bahwa tingkat pendidikan penduduk wilayah ini masih tergolong rendah. Hal ini harus menjadi bahan pertimbnagan dalam melakukan kegiatan-kegiatan dalam rangka meningkatkan kesiapsiagaan penanggulangan bencana di wilayah tersbut yang disesuaikan dengan tingkat pendikan

Hasil Analisis situasi dari jumlah rumah menurut sifat rumah penduduk di wilayah Cimahi Selatan, sebanyak 48.946 rumah dengan sifat rumah permanen. Sedangkan sifat rumah semi permanen sebanyak 11.820 rumah. Menurut BPBD Kota Cimahi, rumah yang ditemoati warga belum mempertimbangkan kontruksi bangunan tahan gempa. Hal ini memungkinkan akan adanya dampak yang besar terhadap kerusakan infrastruktur terutama rumah warga.

Hasil analisis situasi dari jumlah sarana kesehatan dan petugas kesehatan di wilayah Cimahi Selatan terdapat sebuah rumah sakit umum dan 2 rumah sakut bersalin, sedangkan poliklinik sebanyak 15 buah. Sedngkan jumlah tenaga kesehatan seperti dokter dan bidan sebanyak 105 orang. Dari berbagai alasan tersebut diatas maka kami tertarik melakukan pengabdian masyarakat dengan judul Kurangi Dampak Bencana Melalui Kematangan Mitigasi Bencana Berbasis Kader Kesehatan Masyarakat Di Kelurahan Utama kecamatan Cimahi Selatan- Kota Cimahi.

\section{MASALAH}

Analisis situasi di Wilayah Cimahi Selatan terdapat permasalahan potensi bencana salah satunya adalah gempa bumi. Wilayah yang dilewati sesar lembang. Dimana pergerakan sesar lembang ini mencapai 3-6 milimeter pertahunnya. Diperkirakan apabila terjadi gempa bisa mencapai 6,8 bahkan bisa mencapai 7 skala richter. Selain itu dari hasil analisis situasi kepadatan penduduk menunjukkan bahwa dari tingkat kepadatan penduduk yang cukup padat, wilayah Cimahi Selatan memungkinkan akan terjadinya dampak korban bencana gempa bumi dengan jumlah krban yang cukup banyak apabila dilihat dari tingkat kepadatan penduduk.

Permasalahan lain adalah rendahnya tingkat pendidikan penduduk Cimahi Selatan harus menjadi bahan pertimbnagan dalam melakukan kegiatankegiatan dalam rangkat meningkatkan kesiapsiagaan penanggulangan bencana di wilayah tersbut yang disesuaikan dengan tingkat pendikan. Selain itu, permasalhan lain diungkapkan BPBD Kota Cimahi, rumah yang ditempati warga 
belum mempertimbangkan kontruksi bangunan tahan gempa. Hal ini memungkinkan akan adanya dampak yang besar terhadap kerusakan infrastruktur terutama rumah warga dan jumlah korban.

Dalam Rangka mensukseskan program pemerintah, upaya peningkatan kesiapsiagaan bencana yang dianjurkan kepada masyarakat tidaklah cukup dari penyulugan atau penyebaran leaflet dan brosur, namun perlu adanya upaya nyata dalam mempersiapkan masyarakan menghadapi ancaman bencana, khususnya gempa bumi yang dapat dilakukan oleh masyarakat secara mandiri.

Upaya kegiatan-kegiatan dalam meningkatkan kesiapsiaaan bencana masyarakat Cimahi Selatan dapat dilakukan dengan melakukan kegiatan penyuluhan berupa kesiapsiagaan bencana yang disertai dengan demostrasi dan simulasi kesiapsiagaan bencana pada setiap tahap, dimulai dari prabencana, intrabencana sampai paska bencana. Kegiatan ini akan memberikan gambaran terhadap keadaan bencana gempa bumi yang mendekati nyata, sehingga masyarakat mampu mempersiapkan diri dalam menghadapi bencana gempa bumi.

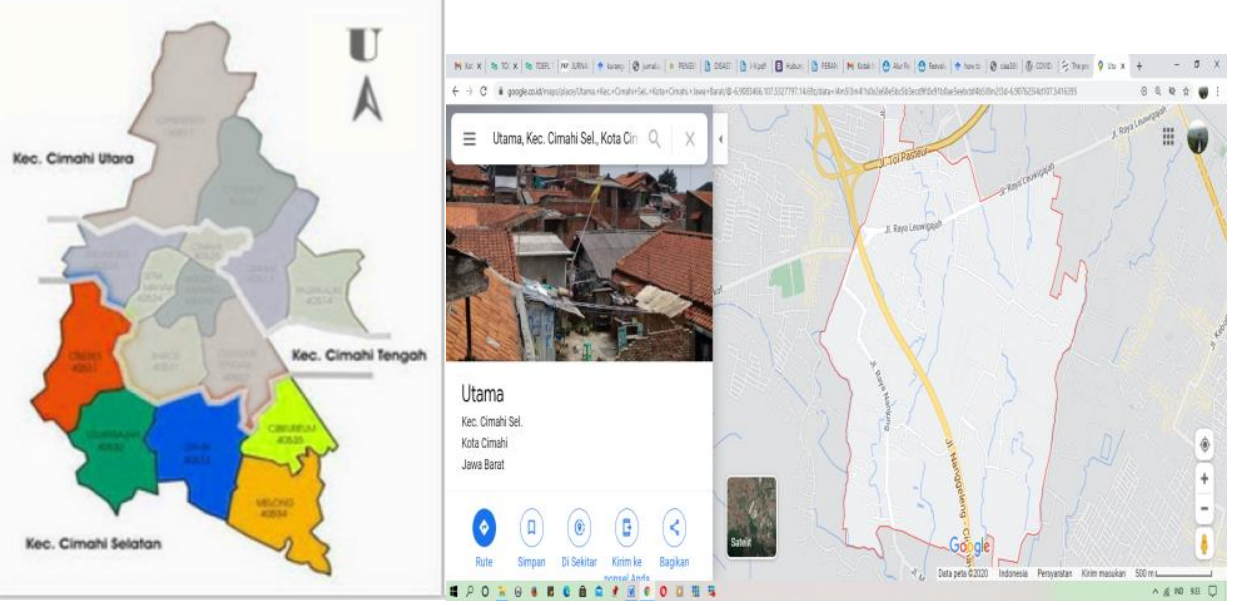

Gambar 2.1 Peta Lokasi Kegiatan Pengbdian Kepada Masyarakat.

\section{METODE}

\section{a. Tujuan Persiapan}

Tahap persiapan dari kegiatan adalah pembuatan pre planning, persiapan penyajian dalam bentuk penyuluhan, simulasi bencana, tempat dan alat-alat lainnya disiapkan di Kantor kelurahan utama. Pembuatan materi penyuluhan, truma healing pasca bencana, Penanggualangan Bencana gempa bumi, Evaluasi Korban Bencana Gempa Bumi, membuat poster Kesiapsiagaan gempa bumi,Penanganan Korban partah tulang/ fraktur dan leafletnya dan lainnya.

\section{b. Tahap pelaksanaan}

Acara ini dengan dengan koordinasi dengan kepala Puskesmas Cimahi Selatan dan dilanjutkan dengan koordinasi dengan Lurah Kelurahan Utama. Setelah itu Lurah menugaskan bagian penanggualangan bencana untuk menginfokan kepada para kader dengan mengirimkan 2 kader tiap RW dan ketua RW di kelurahan utama sehingga terkumpul sebanyak 50 peserta pelatihan. Dan mereka berkumpul di audotorium kelurahan utama untuk menerima penyuluhan, kemudian dilakukan demontrasi bagaimana 
penanganan bencana pre, intra dan post gempa bumi dan juga langsung simulasi tekait penanganan bencana gempa bumi di ruang Audotorium Kelurahan Utama.

c. Evaluasi

i. Struktur

Peserta hadir sebanyak 50 orang kader kesehatan dan ketua Rw di kelurahan Utama. Setting tempat sudah sesuai dengan rencana yang dibuat dan perlengkapan yang dilakukan untuk penyuluhan sudah tersedia dan sudah digunakan sebagaimana mestinya baik spanduk, alat peraga untuk demontrasi pertolongan patah tulang, kemudian juga triage untuk pertolongan pertama saat terjadi bencana gempa bumi. Penggunaan bahasa yang digunakan sudah komunikatif dalam penyampaiannya. Untuk simulasi juga bisa di laksanakan dengan baik. .Para peserta mampu melakukan simulai pra, Intra dan post bencana gempa bumi dengan baik.

ii. Proses

Pelaksanaan kegiatan pukul 09.00 s/d 12.00 WIB. Sesuai dengan jadwal yang telah direncanakan.

\section{HASIL DAN PEMBAHASAN}

Pelaksanaan pelatihan di lakukan kepada Kader Kesehatan di wilayah kelurahan Utama, sebanyak 50 orang. Kader kesehatan di dominasi oleh ibu ibu dengan umur antara 35-50 tahun. Mereka mendapatkan penyuluhan, kemudian dilanjutkan dengan simulasi yang diberikan oleh fasilitator dan selanjutnya langsung role play/demonstrasi yang dilakukan kader kesehatan. Para Kader memahami terkait mitigasi bencana saat dilakukan tanya jawab disetiap penyuluhan. Setelah itu mereka juga mampu melakukan simulasi dan role play langsung dimana satu orang sebagai komando dan lainnya sebagai masyarakat biasa. Menurut Suwaryo \& Yuwono (2017) faktor umur merupakan faktor dominan yang mempengaruhi tingkat pengetahuan warga masyarakat tentang mitigasi bencana alam tanah longsor. Oleh karena itu, perlu adanya sosialisasi terkait mitigasi bencana dan peran masyarakat untuk meningkatkan manajemen bencana. Informasi terkait mitigasi bencana sangat penting bagi masyarakat di wilayah kelurahan Utama dan para kader sangat antusias dalam menyimak penyuluhan dan juga melakukan simulasi mitigasi bencana dengan baik. Kurniawan (2019) faktor personal dan informasi yang didapatkan mempengaruhi seseorang untuk bersikap dan memiliki suatu niat dalam tanggap bencana. Griffithi (2019) Peran Kelompok Siaga Bencana Masyarakat sangat di butuhkan dalam penanganan bencana dan juga kerjasama diantara kelompok siaga bencana. Kondisi kegawatdaruratan dapat terjadi dimana saja dan kapan saja. Sudah menjadi tanggung jawab petugas kesehatan untuk menangani masalah tersebut. Namun tidak menutup kemungkinan kondisi kegawatdaruratan dapat terjadi pada daerah yang sulit dijangkau oleh petugas kesehatan. Sehingga pada kondisi tersebut peran serta masyarakat khususnya kader kesehatan untuk membantu korban sebelum ditangani oleh petugas kesehatan ahli menjadi sangat penting (Samsir et al, 2020).

Berikut gambar pelaksanaan kegiatan: 


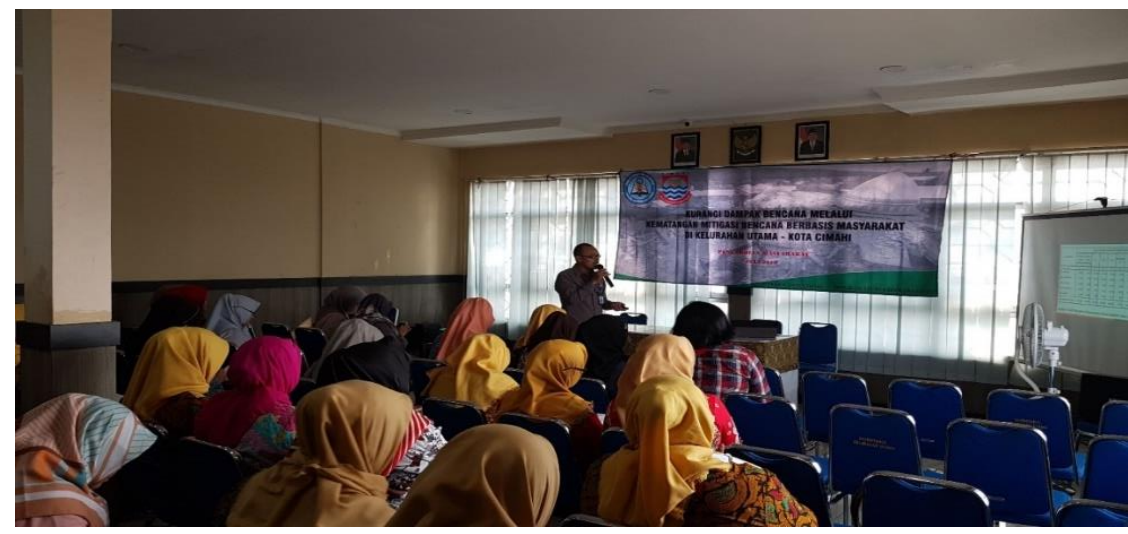

Gambar 2.2 Foto Kegiatan PKM

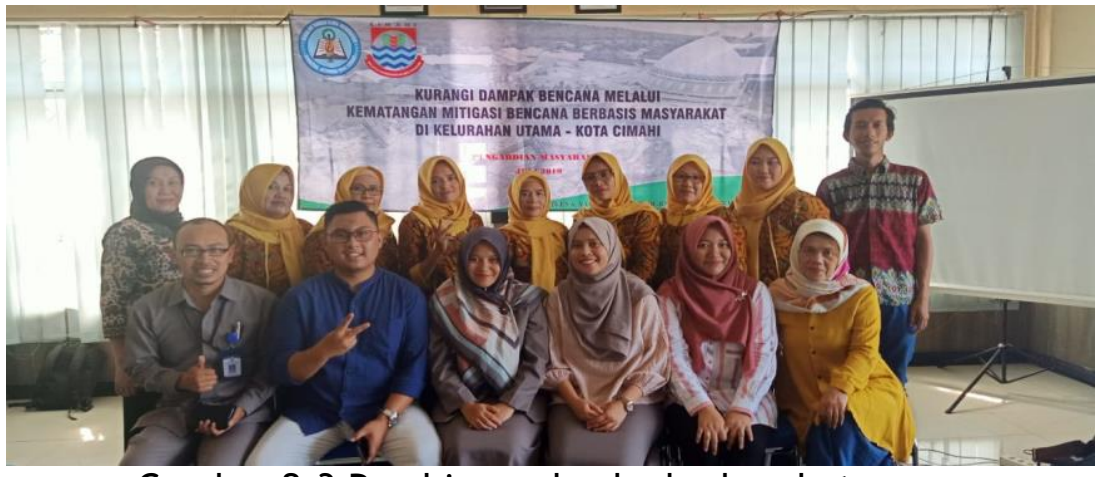

Gambar 2.3 Pembicara dan kader kesehatan

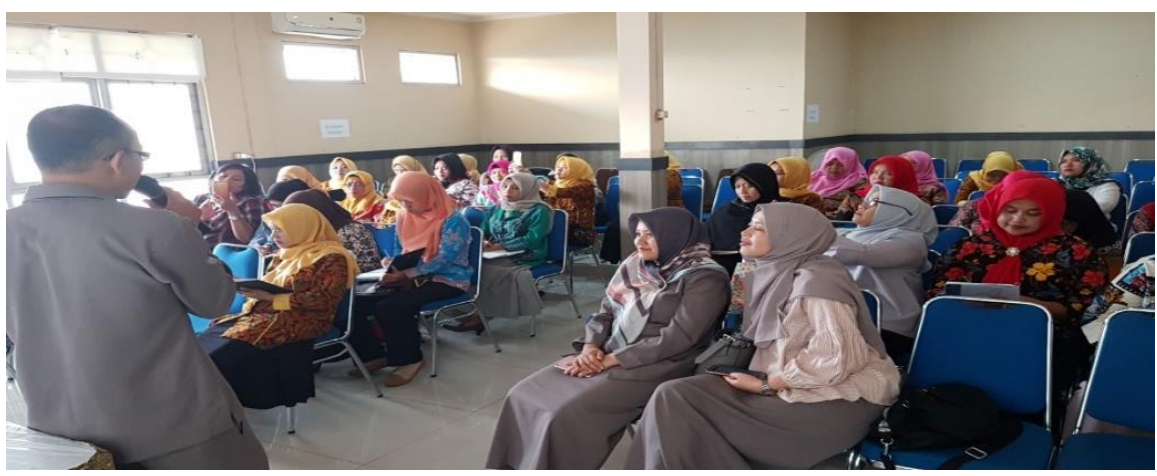

Gambar 2.4 Pemaparan Materi

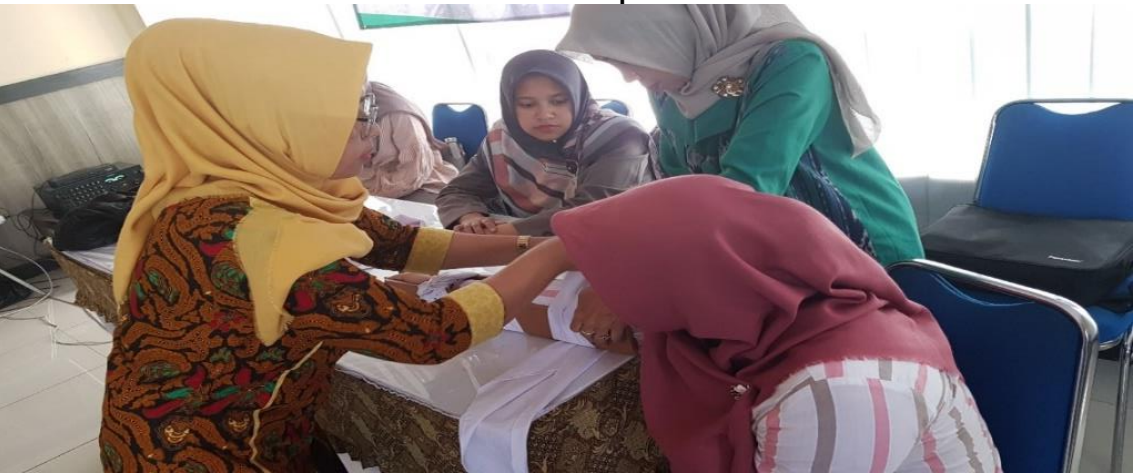

Gambar 2.5 Simulasi Balut \& Bidai oleh Kader Kesehatan 


\section{KESIMPULAN}

Kegiatan ini dapat dilakukan oleh kader kesehatan dan juga ketua RW ataupun masyarakat yang tergolong masyarakat rentan seperti. Kegiatan pengabdian masyarakat ini dilakukan dengan memiliki jenis dari solusi permasalahan di wilayahKelurahan Utama yang masuk dalam wilayah Kerja Puskesmas Cimahi Selatan berupa peningkatan kemampuan kesiapan dalam menghadapi bencana gempa bumi.Kegiatan pelatihan mitigasi bencana ini merupakan bentuk kegiatan yang positif yang harus dikembangkan sehingga bemanfaat untuk kader kesehatan masyarakat dan bisa sampaiakan kepada masyarakat umum juga bisa diterapkan dalam kehidupan sehari-hari .

\section{DAFTAR PUSTAKA}

Amri, M, R et al. (2016). RBI Risiko Bencana Indonesia. Badan Nasional Penanggulangan Bencana: Jakarta.

[BNPB] Badan Nasional Penanggulangan Bencana (BNPB). (2011). Indeks Rawan Bencana Indonesia Tahun 2011. Jakarta

[BNPB] Badan Nasional Penanggulangan Bencana (BNPB). (2012). Pedoman Umum Pengkajian Risiko Bencana. Jakarta

Fernalia, F., Pawiliyah, P., Triana, N., Direja, A. H. S., Juksen, L., Listiana, D., \&

Rahmawati, I. (2020). Penyuluhan Dan Simulasi Management Disaster Di Madrasah Aliyah Negeri Model 01 Kota Bengkulu. JURNAL KREATIVITAS PENGABDIAN KEPADA MASYARAKAT (PKM), 3(1), 170-177.

Peraturan Kepala Badan Nasional Penanggulangan Bencana. (2008). Nomor 4 Tahun 2008 Tentang Pedoman Penyusunan Rencana Penanggulangan

Profil Kesehatan Kota Cimahi. (2017). Pemerintah Kota Cimahi

Profil Kesehatan Kota Cimahi Selatan. (2015). Pemerintah Kota Cimahi

Sabrini, S. Y. (2019). Disaster Book Angin Puting Beliung Sebagai Upaya Pendidikan Mitigasi Bencana Di Sd N Nusajati 3 Kecamatan Sampang Kabupaten Cilacap (Doctoral dissertation, UNNES).

Santiria Griffithi, S. (2019). Peran Serta Kelompok Siaga Bencana Terhadap Pengetahuan Dan Sikap Kesiapsiagaan Bencana Banjir Masyarakat Kelurahan Kalipancur (Doctoral dissertation, UNNES).

Samsir, S., Zakariyati, Z., \& Yunus, M. (2020). Sosialisasi Dan Pelatihan Teknik Pembidaian Kasus Patah Tulangpada Masyarakat Desa Romangloe Kecamtan Bontomarannu Kabupaten Gowa. Jurnal Kreativitas Pengabdian Kepada Masyarakat (PKM), 3(1), 142-147.

Suwaryo, P. A. W., \& Yuwono, P. (2017). Faktor-faktor yang mempengaruhi tingkat pengetahuan masyarakat dalam mitigasi bencana alam tanah longsor. URECOL, 305-314. 